\title{
Pengaruh Pemberian Infusa Daun Bangun-Bangun (Coleus amboinicus, Lour) Terhadap Performa Broiler
}

\section{The Effect of Infusa Bangun-Bangun Leaves (Coleus amboinicus, Lour) in Broiler Performance}

\author{
Nelzi Fati', Ramond Siregar ${ }^{1}$ dan Ulva Mohtar Lutfi ${ }^{1}$ \\ 'Program Studi Budi Daya Ternak, Politeknik Pertanian Negeri Payakumbuh \\ Jl. Raya Negara Km. 7 Tanjung Pati, 26271, Payakumbuh \\ nelzifati@gmail.com
}

$\begin{array}{ll}\text { Diterima } & : \text { 26 Januari } 2019 \\ \text { Disetujui } & : \text { 11 Februari } 2019 \\ \text { Diterbitkan } & : 21 \text { Februari } 2019\end{array}$

\begin{abstract}
Abstrak: $\quad$ Penelitian ini untuk mengetahui pengaruh pemberian infusa daun bangun-bangun terhadap performa ayam pedaging. Metode yang digunakan Rancangan Acak Lengkap (RAK) dengan 5 (lima) perlakuan dan 4 (empat) ulangan, metode yang digunakan Rancangan Acak Lengkap RAL). Setiap unit percobaan ditempati oleh lima ekor ayam. Penelitian ini menggunakan lima taraf perlakuan infusa daun bangun-bangun (Coleus amboinicus, Lour) dalam air minum dan empat ulangan. Perlakuan $A 1=0 \%$ infusa daun bangun-bangun, perlakuan $A_{2}=0,5 \%$ infusa daun bangun-bangun, $A_{3}=1 \%$ infusa daun bangun-bangun, $A_{4}=1,5 \%$ infusa daun bangun-bangun, dan $A_{5}=2 \%$ infusa daun bangun-bangun. Pemberian infusa daun bangun-bangun dalam air minum tidak signifikan $(P>0,05)$ pada pertambahan bobot badan, konsumsi, dan konversi pakan. Disimpulkan dari penelitian ini: pemberian infusa daun bangun-bangun dapat ditoleransi hingga $2 \%$ dalam hal berat badan, konsumsi ransum dan konversi ransum. Penambahan bobot tertinggi diperoleh pada pemberian $2 \%$ infusa dalam air minum.
\end{abstract}

Kata Kunci: Broiler, Daun Bangun-bangun, Infusa dan Performa.

Abstract: This study attempts to know the influence of infusa leaves bangun-bangun to broiler performance. The design used was completely randomized design (CRD) with 5 (five) treatment and 4 (four) replication. Each experimental unit is occupied by five chickens. As the treatment is five infusa leaves bangun-bangun (Coleus amboinicus, Lour) in drinking water. Treatment A1: o\% infusa leaves bangun-bangun, Treatment $A_{2}: 0.5 \%$ infusa leaves bangun-bangun, $A_{3}=1 \%$ infusa leaves bangun-bangun, $A_{4}=1.5 \%$ infusa leaves bangun-bangun and $A_{5}=$ $2 \%$ infusa leaves bangun-bangun. Giving infusa leaves in drinking water was not significant (P>0.05) on broiler body weight gain, consumption and feed coversion. Concluded from this study : the provision of infusa leaves bangun-bangun can tolerated to $2 \%$ in drinking water to increase body weight, consumption rations and feed conversion. Addition of weights highest obtained in the provision of $2 \%$ in drinking water.

Keywords: Broiler, Bangun-bangun Leaves, Infusa and Performance.

\section{Pendahuluan}

Penyediaan pangan alami, aman, dan berkualitas menjadi tantangan besar bagi pelaksana khususnya bidang pangan. Kebijakan pemerintah Indonesia tentang ketahanan pangan adalah menghasilkan produk peternakan (daging, telur dan susu) dalam jumlah yang cukup, murah terjangkau dan standar kualitas yang sesuai SNI. Salah satu langkah yang dapat digunakan adalah dengan mengurangi atau mengganti pemakaian bahan kimia dalam campuran pangan serta menggantinya dengan bahan alami yang tersedia di alam atau dengan istilah kembali kea lam. Kelompok masyarakat di Negara Eropa telah menetapkan bahwa tanggal 1 Januari 2006 (didasarkan regulasi no 183/2003) yang merupakan tonggak dalam pemusnahan berbagai macam penggunaan antibiotik, dimana puluhan tahun sebelumnya peternak sering menggunakan antibiotik di berbagai Negara di dunia ini.

Tidak dapat dibantah bahwa penggunaan antibiotik dalam pakan ternak sebagai senyawa promotor pertumbuhan, dapat meningkatkan pendapatan dari peternak akibat dari kemampuan senyawa tersebut yang dapat merubah nutrisi pakan secara efisien. Pemakaian antibiotik dalam ransum telah menjadi topik pembicaraan yang utama bagi para ilmuwan, kadang kala terjadi perdebatan sengit akibat efek buruk pada konsumen yang ditimbulkan 
dari mengkonsumsi produk ternak yang dalam pakannya mengandung antibiotik tersebut. Sebagian Negara Eropa, bukanlah merupakan hal yang baru dalam tindakan pelarangan penggunaan antibiotik dalam ransum.

Pada tahun 1986 di Negara Swedia, tahun 1995 di Negara Denmark dan tahun 1999 di Negara Swiss, telah melakukan pembatasan dalam pemberian zat aditif dalam pakan ternak, karena telah ditemukannya resistensi mikroba dalam residu pada hasil ternak akibat dari pemberian antibiotik, sehingga menimbulkan ide untuk mencari alternatif dalam penggantian tersebut.

Resistensi mikroba dapat dipindahkan melalui kontak langsung dengan ternak, ataupun jika mengkonsumsi produk hewani, serta bahan-bahan makanan yang diawetkan dengan menggunakan zat antibiotik. Bakteri akan berkoloni dalam tubuh manusia dan juga dapat mengakibatkan berbagai gangguan kesehatan, bahkan dapat menimbulkan kematian.

Salah satu alternatif dalam mengurangi penggunaan antibiotika tersebut adalah pemberian tanaman herbal dalam ransum yaitu daun bangunbangun. Coleus amboinicus, Lour (Daun bangunbangun) telah lama dimanfaatkan oleh masyarakat Batak yang telah dikembangkan dan digunakannya. Menurut masyarakat Batak yang mengkonsumsi daun bangun-bangun ini berkhasiat dalam menjaga dan meningkatkan kesehatan tubuh, disamping sangat bermanfaat sekali bagi ibu-ibu yang menyusui karena dapat meningkatkan produksi susunya. Daun bangun-bangun juga bermanfaat untuk mengatasi demam, batuk, influenza, sembelit, radang, sariawan, sakit kepala, alergi, diare serta meningkatkan produksi susu [1]. Bangun-bangun merupakan sejenis tanaman yang tidak berkayu atau mempunyai jaringan kayu hanya sedikit, berbatang lunak, akibatnya pada akhir hidupnya akan mati sampai ke pangkalnya sehingga tidak ada bagian batang yang tertinggal di atas tanah. Bangun-bangun merupakan tanaman tahunan atau annual [2], biasa hidup liar dalam pekarangan, hidup pada daerah dengan ketinggian $1000 \mathrm{~m}$ atau $1100 \mathrm{mdpl}$, juga pada daerah pegunungan serta juga dimanfaatkan sebagai tanaman rempah-rempah [3].

Hasil penelitian didapatkan identifikasi tanaman bangun-bangun di tiga wilayah Sumatera Barat adalah menunjukkan ciri-ciri morfologi yang hampir sama, hal ini disebabkan syarat tumbuh ketiga tempat hampir sama, namun wilayah Padang Panjang merupakan tempat yang paling memenuhi syarat tumbuh tanaman ini [4]. Hal ini dapat dilihat dari kondisi lingkungan, tinggi tanaman $(50-100 \mathrm{~cm})$, jumlah cabang per tanaman (9-24 buah), panjang daun $(5-8 \mathrm{~cm})$, lebar daun $(5-8 \mathrm{~cm})$, panjang tangkai daun $(4-7 \mathrm{~cm})$ dan jumlah daun per tanaman (97-206 buah). Disamping itu daun bangun-bangun diketahui mengandung senyawa aktif thymol yang berfungsi sebagai antibiotik alternatif. Daun bangun-bangun juga mengandung senyawa carvacrol yang dikenal sebagai senyawa antiinfeksi dan antiinflamasi, senyawa $\alpha$-Terpinene dan $\gamma$-Terpinene yang berfungsi sebagai antioksidan. Secara keseluruhan daun bangun-bangun berfungsi sebagai senyawa farmakoseutika yang berfungsi sebagai senyawa yang bersifat buffer, antibacterial, antioksidan, pelumas, pelentur, pewarna dan penstabil [5]. Penggunaan produk tanaman yang mempunyai fungsi sebagai tanaman obat yang banyak terdapat di Indonesia khususnya Sumatera Barat semakin dikembangkan karena sebagai pakan tambahan alami pengganti antibiotik komersial. Usaha pengembangan dan memanfaatkan tanaman obat tradisional yang berfungsi sebagai obat dan telah dapat dimanfaatkan secara luas pada masyarakat, sehingga dilakukan penelitian dalam rangka pendayagunaan sumber daya alam yang berpotensi, juga dapat digunakan untuk meningkatkan status kesehatan, zat gizi sehingga dapat meningkatkan kualitas produk daging broiler yang bebas dari antibiotik sintetik.

Berdasarkan hal yang telah tersebut di atas diangkatlah judul penelitian "Pengaruh pemberian infusa daun bangun-bangun (Coleus amboinicus, Lour) terhadap performa broiler".

Tujuan Penelitian adalah: Untuk mengetahui pengaruh infusa daun bangun-bangun terhadap performa broiler dan untuk mendapatkan level yang terbaik dari pemberian infusa daun bangun-bangun terhadap performa broiler.

\section{Materi dan Metode}

\subsection{Tempat dan waktu}

Penelitian ini dilaksanakan di UPT Farm dan Laboratorium Peternakan Politeknik Pertanian Negeri Payakumbuh selama 6 (enam) bulan.

\subsection{Alat dan bahan}

a). Ternak. Pada penelitian ini menggunakan sebanyak 100 ekor DOC tanpa pemisahan jenis kelamin.

b). Infusa daun bangun-bangun (Coleus amboinicus, Lour)

c). Ransum komersial. Ransum yang digunakan adalah ransum komersial dengan kadar protein sekitar $21 \%-22 \%$, kandungan energi sekitar 2900-3000 kkal/ kg.

d). Kandang. Kandang per unit perlakuan dengan ukuran 50 x $50 \mathrm{~cm}$ dengan tinggi sekat $60 \mathrm{~cm}$ yang masing-masing unit terdiri dari 5 ekor.

e). Timbangan pakan dan timbangan Ohaus kapasitas $2 \mathrm{~kg}$.

f). Daun bangun-bangun (dalam bentuk kering).

g). Gelas ukur. 


\subsection{Metode pelaksanaan}

Penelitian dilakukan terhadap 100 ekor DOC broiler. Ransum yang digunakan adalah ransum komersial dengan kadar protein $21 \%$ - 22\%, serat kasar di bawah $5 \%$ dengan kandungan Energi Metabolisme $2900-3000$ Kkal.

Seratus ekor DOC broiler dibagi secara acak ke dalam 20 unit percobaan. Tiap unit kandang perlakuan ditempati 5 ekor DOC dan masing-masing individu ditempatkan secara acak tiap unit kandang perlakuan.

Cara pembuatan larutan infusa; sebanyak $10 \mathrm{~g}$ serbuk daun bangun-bangun ditimbang ditambah air suling sebanyak $100 \mathrm{ml}$ air yang dimasukkan dalam panci untuk membuat infusa. Kemudian dilakukan pemanasan di atas penangas air menggunakan panci infusa dengan waktu 15 menit terhitung suhu mencapai $90{ }^{\circ} \mathrm{C}$, sambil sesekali diaduk. Setelah itu diserkai dalam keadaan panas-panas menggunakan kain flanel hingga didapat volume $100 \mathrm{ml}$, bila jumlah belum tercapai dilakukan penambahan air panas pada ampas lalu diserkai hingga didapat volume 100 $\mathrm{ml}$.

\subsection{Rancangan penelitian}

Penelitian ini menggunakan Rancangan Acak Lengkap dengan 5 perlakuan dan 4 ulangan sehingga jumlah unit percobaannya 20 unit yang masingmasing unit terdiri dari 5 ekor DOC broiler. Sebagai perlakuan adalah 5 level infusa daun bangun-bangun (Coleus amboinicus, Lour) dalam air minum.

Perlakuan level infusa daun bangun-bangun (Coleus amboinicus, Lour) dalam air minum adalah:

a). $A_{1}=0 \%$ infusa daun bangun-bangun dalam air minum

b). $A_{2}=0,5 \%$ infusa daun bangun-bangun dalam air minum

c). $A_{3}=1 \%$ infusa daun bangun-bangun dalam air minum

d). $A_{4}=1,5 \%$ infusa daun bangun-bangun dalam air minum

e). $A_{5}=2 \%$ infusa daun Bangun-bangun dalam air minum

Guna mengetahui pengaruh perlakuan, data yang diperoleh dianalisis dengan sidik ragam, dan dilanjutkan dengan uji DMRT bila ada perbedaan antara perlakuan [6].

Parameter yang diukur adalah PBB, konsumsi dan konversi ransum.

\section{Hasil dan Pembahasan}

\subsection{Pertambahan bobot badan}

Pemberian infusa daun bangun-bangun dalam air minum berpengaruh tidak nyata $(\mathrm{P}>0,05)$ terhadap pertambahan bobot badan broiler.
Pertambahan bobot badan rata-rata dapat dilihat pada Tabel 1.

Tabel 1. Rata-rata pertambahan bobot badan, konsumsi ransum dan konversi ransum selama penelitian

\begin{tabular}{cccc}
\hline Perlakuan & $\begin{array}{c}\text { Pertambahan } \\
\text { Bobot Badan } \\
\text { (g/ekor) }\end{array}$ & $\begin{array}{c}\text { Konsumsi } \\
\text { Ransum } \\
\text { (g/ekor) }\end{array}$ & $\begin{array}{c}\text { Konversi } \\
\text { Ransum }\end{array}$ \\
\hline A1 & $1357 \pm 12.08$ & $2061,00 \pm 82,53$ & $1,52 \pm 0,06$ \\
A2 & $1349,75 \pm 42$ & $2113,75 \pm 50,31$ & $1,57 \pm 0,23$ \\
A3 & $1365,75 \pm 49,7$ & $2115,25 \pm 28,46$ & $1,59 \pm 0,02$ \\
A4 & $1382,5 \pm 60,16$ & $2080,00 \pm 46,73$ & $1,51 \pm 0,01$ \\
A5 & $1415,25 \pm 25,3$ & $2040,25 \pm 82,91$ & $1,45 \pm 0,03$ \\
\hline
\end{tabular}

Tabel 1 menunjukkan bahwa pertambahan bobot terendah (1349,75 g) dicapai pada perlakuan (A2) dengan pemberian infusa daun bangun-bangun $0,5 \%$ dalam air minum sedangkan pertambahan bobot badan yang tertinggi (1415,25 g) diperoleh pada perlakuan (A5) dengan pemberian infusa daun bangun-bangun $\mathbf{2} \%$ dalam air minum. Secara berurutan pertambahan bobot badan yang terendah sampai tertinggi adalah A2 (1349,75 g), A1 (1357 g), A3 (1365,75 g), A4 (1382,5 g) dan A5 (1415,25 g).

Hasil sidik ragam didapatkan bahwa perlakuan berpengaruh tidak nyata $(\mathrm{P}>0,05)$ terhadap pertambahan bobot badan broiler. Pertambahan bobot badan rata-rata hasil penelitian ini adalah 1349,75 g - 1415,25 g seperti yang tertera pada Tabel 1. Grafik pertambahan bobot badan (Gambar 1) sampai umur 4 minggu. Gambar 1 memperlihatkan bahwa terjadinya peningkatan bobot badan dibandingkan kontrol walaupun tidak signifikan.

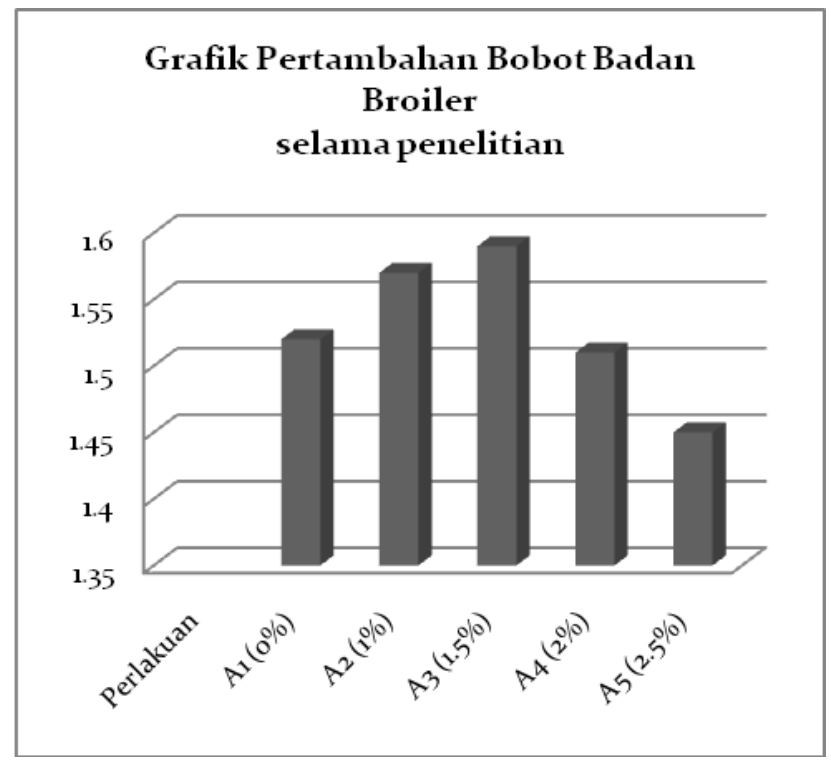

Gambar 1. Grafik pertambahan bobot badan selama penelitian 
Broiler yang dipelihara sampai umur 4 minggu pada penelitian ini terlihat pertambahan bobot badan dengan dosis infusa daun bangun-bangun $\left(\mathrm{A}_{5}\right)$ yaitu 2\% dalam air minum lebih tinggi secara angka dibandingkan dengan pemberian infusa $0,5 \%, 1 \%$ dan $1,5 \%$ dalam air minum. Hal ini diduga karena pemberian infusa daun bangun-bangun yang mengandung minyak atsiri sampai $2 \%$ dalam air minum dapat membantu ayam memperbaiki performa, yaitu membantu meningkatkan penyerapan zat-zat makanan [7].

Pada penelitian broiler yang memberikan ekstrak daun beluntas dalam air minum juga mengandung minyak atsiri didapatkan pertambahan bobot badan umur 4 minggu berkisar 721-889 g/ekor [8]. Lebih lanjut dinyatakan semakin meningkat pemakaian taraf infusa daun beluntas menyebabkan penurunan bobot badan broiler. Sedangkan dari hasil penelitian pemberian infusa daun selasih sampai 12 $\mathrm{ml} /$ liter air minum tidak menurunkan pertambahan bobot badan [9], hal ini berarti pemakaian sampai 12 $\mathrm{ml} /$ liter air minum belum berdampak menurunkan pertambahan bobot badan broiler. Dengan meningkatnya taraf pemberian daun beluntas berakibat menurunkan pertambahan bobot badan akibat dari adanya peran yang berlawanan antara zat-zat aktif daun beluntas yaitu minyak atsiri dengan kandungan flavonoid, saponin dan tanin [8], karena zat-zat aktif tersebut dapat mengurangi pemanfaatan ransum yang mengikat protein dan enzim pencernaan sehingga pertumbuhan menjadi terhambat.

Pertambahan bobot yang tinggi dari pemberian infusa daun bangun-bangun dapat dicapai pada pemberian infusa daun bangun-bangun $2 \%$ dalam air minum. Hal ini diduga karena daun bangun-bangun mengandung senyawa forskolin yang mempunyai bersifat membakar lemak menjadi energi [10], sehingga tidak terjadi kehilangan energi akibat panting karena sebesar 575 kalori panas dibutuhkan untuk menguapkan satu gram air [8], sedangkan energi yang dihasilkan ternak dibutuhkan untuk menjalani proses-proses yang ada dalam tubuh. Berdasarkan hasil penelitian ini pemberian infusa daun bangun-bangun 2\% dalam air minum dapat ditolerir broiler terhadap pertambahan bobot badan.

\subsection{Konsumsi ransum}

Hasil sidik ragam didapatkan bahwa perlakuan berpengaruh tidak nyata $(\mathrm{P}>0,05)$ terhadap konsumsi ransum broiler. Rataan konsumsi ransum broiler hasil penelitian ini adalah 2040,25 g - 2115,25 g seperti yang terlihat pada Tabel 1.

Grafik konsumsi ransum broiler selama penelitian dapat dilihat pada Gambar 2. Konsumsi ransum broiler hampir sama dari tiap perlakuan, hal ini karena broiler mendapatkan ransum yang sama, sehingga palatabilitasnya juga sama. Terdapatnya sedikit perbedaan dalam konsumsi ransum masingmasing perlakuan adalah karena broiler mengkonsumsi infusa daun bangun-bangun dalam air minum dengan dosis yang berbeda. Pemberian infusa daun bangun-bangun dapat ditolerir sampai 2\% dalam air minum terhadap konsumsi ransum.

Rataan konsumsi ransum yang mendapatkan infusa daun bangun-bangun $2 \%$ dalam air minum lebih rendah dibandingkan kontrol, dan perlakuan infusa daun bangun-bangun lainnya. Hal ini diduga dari kandungan minyak atsiri yang terdapat pada infusa daun bangun-bangun dapat merelaksasi usus halus, sehingga mengurangi gerakan peristaltik usus yang mengakibatkan laju ingesta di dalam saluran pencernaan menjadi lambat, hal ini secara tidak langsung akan mengurangi jumlah ransum yang dikonsumsi, akan tetapi walaupun konsumsi ransum lebih rendah dari perlakuan lainnya, pertambahan bobot badannya secara angka menunjukkan lebih tinggi dibandingkan dengan pemberian infusa $0,5 \%$, $1 \%$ dan $1,5 \%$ dalam air minum. Hal ini berarti pemberian infusa daun bangun-bangun dapat mengefisienkan ransum yang dikonsumsi broiler. Hasil penelitian [9] dilaporkan bahwa konsumsi ransum broiler adalah berkisar $1788 \mathrm{~g}-1951,25 \mathrm{~g}$ lebih rendah dari hasil penelitian ini yaitu $2040 \mathrm{~g}-\mathbf{2 1 1 5 , 2 5}$ g. Kurkuminoid dan minyak atsiri pada kunyit dan temulawak dalam ransum dapat mengurangi rataan konsumsi ransum [11], akan tetapi kandungan minyak atsiri yang terdapat dalam infusa daun bangunbangun sampai $2 \%$ dalam air minum konsumsi ransumnya lebih rendah dibandingkan pemberian $0,5 \%$ - 1,5\% dalam air minum, akan tetapi tidak menurunkan pertambahan bobot badan broiler.

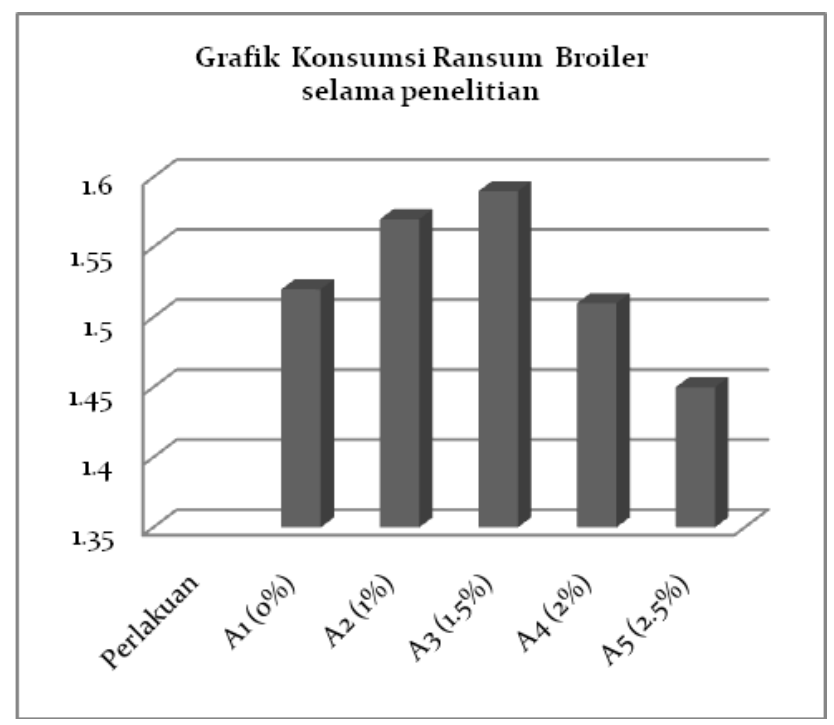

Gambar 2. Konsumsi ransum broiler selama penelitian 


\subsection{Konversi ransum}

Konversi ransum merupakan tolok ukur untuk mengetahui banyaknya ransum yang dikonsumsi dalam menghasilkan $1 \mathrm{~kg}$ daging. Hasil sidik ragam didapatkan bahwa perlakuan berpengaruh tidak nyata $(\mathrm{P}>0,05)$ terhadap konversi ransum broiler. Rataan konversi ransum broiler hasil penelitian ini adalah 1,45 - 1,59. Grafik yang menggambarkan konversi ransum penelitian dapat dilihat pada Gambar 4. Rataan konversi ransum pada perlakuan yang diberi infusa daun bangun-bangun $2 \%$ dalam air minum lebih rendah $(1,45)$ dibanding perlakuan lainnya yaitu 1,51-1,59. Hasil penelitian [9], konversi ransum broiler yang diberi infusa daun selasih berkisar 1,48-1,56. Rendahnya konversi ransum yang diberi infusa daun bangun-bangun $2 \%$ dalam air minum, karena ayam tersebut mengonsumsi pakan yang lebih sedikit dibandingkan dengan perlakuan $0,5 \%, 1 \%$ dan $1,5 \%$ infusa daun bangun-bangun dalam air minum serta pertambahan bobot badannya lebih tinggi dibandingkan dengan perlakuan lainnya sedangkan konsumsi ransum perlakuan lainnya hampir sama dan PBB yang dihasilkan juga hampir sama. Penambahan infusa daun bangun-bangun dapat ditolerir sampai $2 \%$ di dalam air minum terhadap konversi ransum.

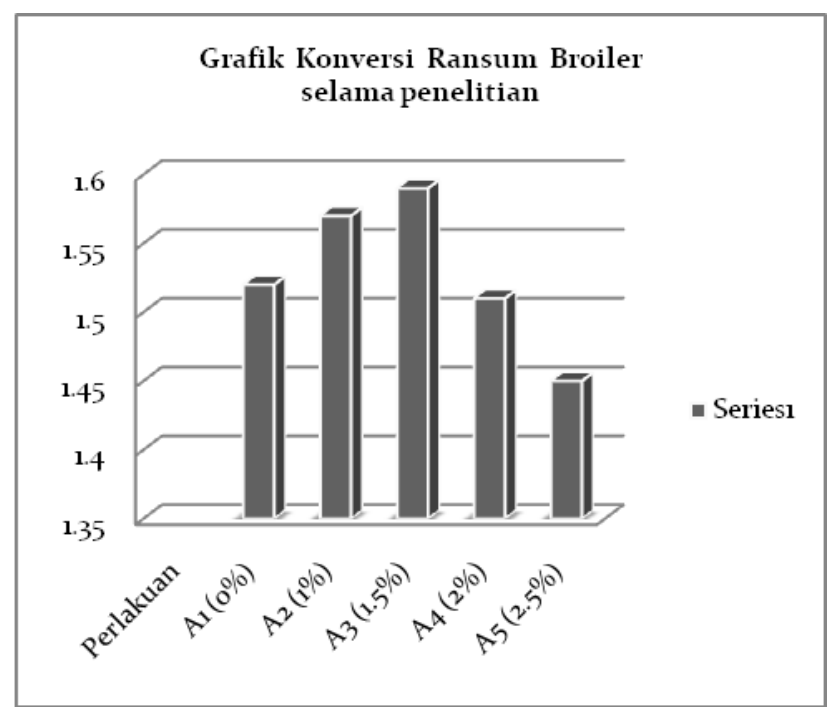

Grafik 3. Konversi ransum selama penelitian

\section{Kesimpulan}

Pemberian infusa daun bangun-bangun dapat ditolerir sampai $2 \%$ dalam air minum terhadap pertambahan bobot badan, konsumsi ransum dan konversi ransum. Pertambahan bobot yang tertinggi didapatkan pada pemberian $2 \%$ dalam air minum.

\section{Referensi}

[1] [Depkes] Departemen Kesehatan, 2005. Botani, sinonim nama Umum dan nama Dagang Daun
Bangun-Bangun. Jakarta: Depkes [terhubung berkala]. http://www.iptek.apjii.or.id [5 April 2005].

[2] Heyne, K. 1987. Tumbuhan Berguna Indonesia. Jilid I dan II. Terj. Badan Libang Kehutanan. Cetakan I. Koperasi karyawan Departemen Kehutanan Jakarta Pusat.

[3] [BPPT] Badan Pengkajian dan Penerapan Technology, 2002. Jintan (Coleus amboinicus). Jakarta: Cakrawala IPTEK. [terhubung berkala]. http://iptek.net.id [1o Desember 2007].

[4] Siregar, R., N. Fati, S. Wahono, dan Y. Sondang. 2013. Karakterisasi Daun Bangun-bangun (Coleus amboinicus L.) daerah Sumatera Barat. Proseding Seminar Nasional, Optimalisasi Sistem Pertanian Terpadu dan Mandiri Menuju Ketahanan Pangan. ISBN: 978-979-98691-3-5, hal 292-298, 30 Oktober 2013.

[5] Lawrence M, Naiyana, Damanik MRM, 2005. Modified Nutraceutical Composition Australia: Freehills patent and trademark Attorneys Melbourne. [terhubung berkala]. http://www.wipo.int/pstdb [10 Desember 2007].

[6] Steel, R.G.D. dan J.H. Torrie. 1993. Prinsip dan prosedur statistika suatu pendekatan biometrik. Cetakan Ke 2. (Alih bahasa, Sumantri. B). Penerbit PT. Gramedia, Jakarta. Dies Natalis Institut Teknologi Bandung.

[7] Mursito, B. 20oo. Ramuan tradisional untuk kesehatan anak. Penebar Swadaya, Jakarta.

[8] Kaniadewi, R.R. 2006. Pengaruh pemberian ekstrak daun beluntas (Plucheaindica less) pada air minum terhadap performan ayam broiler pada kepadatan kandang yang tinggi. Fakultas Peternakan IPB, Bogor.

[9] Mulyani, R., W. Agrianto, N. Mardiana dan T. D. Hermanto. 2016. Pengaruh Pemberian Infusa Daun Selasih (Ocimum basilicum L.) Dalam Air Minum Terhadap Pertambahan Bobot Badan Broiler. Laporan penelitian. Politeknik Pertanian Negeri Payakumbuh (belum diterbitkan).

[10] Sahelian, R. 2006. Forskolin Mechanism of Action. http://www.PNP.com (17 September 2007).

[11] Rosalyn EM. 2005. Pengaruh pemberian kunyit (Curcuma domestica Val.) atau temulawak (Curcuma xanthorriza Roxb.) dalam ransum terhadap performan broiler [skripsi]. Bogor: Fakultas Peternakan, Insitut Pertanian Bogor. 